\title{
Cost of Capital and Corporate Earning of Nigeria Quoted Firms: A Multi-Dimensional Analysis of Quoted Firms in Nigeria
}

\author{
Lucky Anyike Lucky ${ }^{1}$
}

\begin{abstract}
${ }^{1}$ Department of Banking and Finance, Rivers State University, Nigeria
Correspondence:Department of Banking and Finance, Rivers State University, Nkpolu Orowurokwo, Port Harcourt, Rivers State, Nigeria.Email: lucky.anyike@yahoo.com
\end{abstract}

Received: October 06, 2017

Accepted: October 11, 2017

Online Published: October 14, 2017

\begin{abstract}
This study examined cost of capital and corporate earning of quoted firms in Nigeria. The objective was to examine the effect of short term, medium term and long term cost of capital on earnings per share. Cross sectional data was sourced from financial statement of twenty quoted firms from 2011-2016. Earnings per share was proxy for dependent variable while cost of trade credit, cost of short term bank loans, cost of commercial paper, cost of banker acceptance, cost of line of credit, cost of revolving credit, cost of hire purchase, cost of operating lease, cost of debt, cost of preference share and cost of equity are proxy for independent variables. After cross examination of the validity of the pooled effect, fixed effect and the random effect, the study accepts the fixed and random effect models. Findings reveals that cost of short term and cost of long term have significant relationship with corporate earning while cost of medium term have no significant effect on corporate earnings. It recommends the need for corporate strategies that will reduce cost of capital.
\end{abstract}

Keywords: Cost of Capital, Corporate Earnings, Quoted Firms.

\section{Introduction}

Financing decision of any economic or financial unit, whether a private household, a business firm or government, consists of planning for, generation, and organizing of funds needed for investment and other activities. The two main sources of capital are the equity and debt which both needs to be remunerated at their own cost of capital. Thus, a discussion on financing decisions must include analysis of the various sources through which the units can raise funds, and the associated costs, which is call the cost of capital (Ezirim, 2005). A necessary angle to financing decision would include the determination of the optimal proportions of each form to be utilized by the concerned economic unit, noting the financial implications. The finance management function is a critical success factor and determines the earnings and survival of firms. These functions include the dividend and the financing decision. While the dividend decision determines the proportion of earnings to be distributed to shareholders and proportion to retain, the financing decision determine the optimal combination of debt and equity to maximize shareholders wealth. The cost of equity can be defined as the return expected on a firm's common stock in the capital market. It represents the composition demanded by shareholders for providing capital and assuming the risk of waiting for this return. This implies that cost of equity reflects the opportunity cost of investigating in a firm's stock as opposed to potential investments with similar risks. Cost of 
Cost of Capital and Corporate Earning of Nigeria Quoted Firms: A Multi-Dimensional Analysis of Quoted Firms in Nigeria

debt refers to cost of external source of fund such as cost of long term debt and cost of short term borrowings. Determining optimal cost of capital constitute one of the key finance management functions for financing corporate growth of listed organizations. The central normative preposition of the micro theory of capital is that firms should adjust its capital stock until the marginal rate of return on further investment is equal to the cost of capital (Jonathan \& Lorie, 2007). Under condition of perfect market, certainty which is the basic assumption for the classical theory, develop the concept of capital which means the market rate of interest. Due to the increasing global mobility and flexibility of capital, companies needs to ensure that they offer the required return since the risk of losing their investors which might more costly to the firms.

The firm's cost of capital can be used for discounting the cash flows of the investment projects which have risk equivalent to the average risk of the firm. It is needed for investment and financing decisions, business valuations, capital budgeting and determining recoverable amount for improvement test (Brav, 2009). Cost of capital is used as a discount rate or bench mark return in financing corporate growth. It is used to discount rate for company valuation with the help of the discount cash flow techniques such as the Net Present Value, Internal Rate of Return (Dempsey, 2013). In International Financial Reporting Standard (IFRS), cost of capital is relevant for impairment test as stated by International Accounting Standard (IAS 36). There are limited studies of citable significant that dealt with problem of cost of capital and corporate earnings in Nigeria. Therefore this study intends to examine the effect of cost of capital on corporate earnings of quoted firms in Nigeria. Apart from section one above, section two focuses on both theoretical and empirical review of related literature, section three deals with the research methodology. Section four deals with the data analysis and presentation and the fifth section contain the conclusion and recommendations from the findings.

\section{Literature Review}

A firm raises funds from various sources, which are called the components of capital. Different sources of fund or the components of capital have different costs. The cost of raising funds through issuing equity shares is different from that of raising funds through issuing preference shares. The cost of each source is the specific cost of that source, the average of which gives the overall cost for acquiring capital. The firm invests the funds in various assets. So it should earn returns that are higher than the cost of raising the funds. In this sense the minimum return a firm earns must be equal to the cost of raising the fund. The cost of capital may be viewed from two viewpoints acquisition of funds and application of funds. From the viewpoint of acquisition of funds, it is the borrowing rate that a firm will try to minimize. On the other hand from the viewpoint of application of funds, it is the required rate of return that a firm tries to achieve. The cost of capital is the average rate of return required by the investors who provide long-term funds (Ezirim, 2005). In other words, cost of capital refers to the minimum rate of return a firm must earn on its investment so that the market value of company's equity shareholders does not fall.

\section{Estimating the Cost of Equity Capital}

Estimating the cost of equity involves estimating the expected return on a firm's common stock. The cost of equity includes a risk premium to compensate shareholders for holding a risky equity security rather than a risk-free security:

$$
C O E=E\left(r_{i}\right)=r_{f}+r p_{i}
$$

\section{Where}

$\mathrm{COE}_{i} \quad=\quad$ Firm i's cost of equity, 
Cost of Capital and Corporate Earning of Nigeria Quoted Firms: A Multi-Dimensional Analysis of Quoted Firms in Nigeria

$E\left(r_{i}\right) \quad=\quad$ The expected future return on firm i's equity, where returns include

Capital gains and dividends,

$r_{f} \quad=\quad$ The risk-free rate, and

$r p_{i} \quad=\quad$ The equity risk premium for holding firm i's stock.

Determining the cost of equity using the implied approach is analogous to determining the nominal yield to maturity on a bond. The implied cost of equity is the discount rate that sets the current stock price equal to the present value of expected future dividends per share. The relation between the current stock price $\left(\mathrm{P}_{0}\right)$, the cost of equity ( $r)$, and future expected dividends per share $\left(d_{1}, d_{2}, d_{3} \ldots\right)$ is represented by the dividend discount model (DDM).

$P_{o}=\frac{d_{1}}{(1+r)}+\frac{d_{2}}{(1+r)^{2}}+\frac{d_{3}}{(1+r)^{3}}$

The simplest form of the DDM, the Gordon Dividend Growth Model, assumes a constant perpetual rate of growth (g) in expected dividends per share. With this assumption, dividends are an infinite geometric series, and the cost of equity can be written as a function of the dividend yield plus the constant growth rate:

$r=\frac{d_{1}}{P_{o}}+g$

Residual income valuation (RIV) models address the difficulties in estimating a long term growth rate by utilizing accounting information (Lee, $\mathrm{Ng}$ and Swaminathan, 2004). These models equate the current share price to the sum of two components: (1) the present value of expected dividends per share over a short or medium-term horizon (N); and (2) a discounted terminal value, which is the present value of the expected share price at the end of the forecast period, assuming that dividends then grow at a constant rate $(\mathrm{gL})$ in perpetuity:

$P_{o}=\sum_{t=1}^{N} \frac{d_{t}}{(1+r)^{t}}+\frac{d_{N+1}}{(r-g L)(1+r)^{N}}$

RIV models assume clean surplus accounting which requires that earnings are fully allocated between dividends and retained earnings; whatever portion of earnings that is not paid out in dividends is added to book value of equity. Hence, book value per share $\left(b_{\mathrm{t}}\right)$ evolves according to the following equation:

$b v_{t+1}=b v_{t}+e_{t+1}-d_{t+1}$

and as roe $\quad=\quad$ return on book equity

$$
=\mathrm{e}_{\mathrm{t}} / \mathrm{bv}_{\mathrm{t}-1}
$$

then $\mathrm{bv}_{\mathrm{t}+1}=b v_{t}\left(1+\operatorname{roe}_{t+1}\left(1-\frac{d_{t-1}}{e_{t+1}}\right)\right.$ 
Assuming that return on book equity and the dividend payout ratio after time $\mathrm{N}+1$ remain constant, the following constraint is imposed on the long-term growth rate of dividends per share (gL) in Equation (4)

$$
=g_{L} \operatorname{roe}_{N+1}\left(1-\frac{d_{N-1}}{e_{N+1}}\right)
$$

Claus and Thomas (2001) implement the RIV model using a four-year forecasting horizon $(\mathrm{N}=4)$ and set the growth rate $\left(\mathrm{g}_{\mathrm{L}}\right)$ equal to the expected inflation rate (pe) in order to calculate a nominal cost of equity. 8 Dividends per share in year five are backed out from Equation (6) as follows:

$$
d_{s}=e_{s}\left(1-\frac{g_{L}}{\text { roe }_{5}}\right)=e s\left(1-\frac{\pi_{e}}{\text { roe }_{5}}\right.
$$

So the cost of equity in the Claus and Thomas (2001) model is the value of $r$ that solves the following equation:

$$
P_{o}=\sum_{t=1}^{4} \frac{d_{t}}{(1+r)^{t}}+\frac{d_{5}}{\left(r-\pi_{e}\right)(1+r)^{4}}
$$

If dividends are all positive and the cost of equity is greater than the expected inflation rate, there is only one value of $r$ that will solve this equation.

Another class of implied models assumes that the change in abnormal earnings from year to year grows at a constant rate into perpetuity (Gode and Mohanram, 2003). This is similar to assuming that the forecasted change in dividends grows at a constant rate, if the change in dividends is calculated as:

$$
d_{2}-d_{1}=\left(e_{2}-e_{1}\right)-g_{L}\left(e_{1}-d_{1}\right)
$$

In the Ohlson and Juettner-Nauroth (2003) version, a closed form solution for the cost of equity can be backed out from the following relation between prices, next year's earnings per share estimate and next year's expected dividends per share:

$$
P_{o}=\frac{d_{1}}{r-g_{L}}+\frac{e_{1}\left(g_{s}-g_{L}\right)}{r\left(r-g_{L}\right)}
$$

\section{Where}

$g_{s}=$ Short-term dividends per share growth rate

$$
=\left(e_{2}-e_{1}\right) / e_{1}
$$

$g_{L}=$ A long-term dividends per share growth rate

Easton's (2003) model, called the Modified-PEG ratio model,10 is just a special case of the Ohlson and Juettner-Nauroth model, where the growth rate in the change in dividends is set equal to zero $\left(\mathrm{g}_{\mathrm{L}}=0\right)$ so that dividends grow by the same dollar amount every year into perpetuity. The current stock price is related to the cost of equity, the next two year's forecasted earnings, as well as the next year's dividend: 
Cost of Capital and Corporate Earning of Nigeria Quoted Firms: A Multi-Dimensional Analysis of Quoted Firms in Nigeria

$P_{o}=\frac{d_{1}}{r}+\frac{e_{1} g_{s}}{r^{2}}$

\section{Cost of Debt}

When companies borrow funds from outside or take debt from financial institutions or other resources the interest paid on that amount is called cost of debt. The cost of debt is computed by taking the rate on a risk free bound whose duration matches the term structure of the corporate debt, then adding a default premium. This default premium will rise as the amount of debt increases (since, all other things being equal, the risk rises as the cost of debt rises). Since in most cases debt expense is a deductible, the cost of debt is computed as an after tax cost to make it comparable with the cost of equity (earnings are taxed as well). Thus, for profitable firms, debt is discounted by the tax rate. The formula can be written as:

$\left(\mathrm{R}_{\mathrm{f}}+\right.$ credit risk rate $)(1-\mathrm{T})$

Where $\mathrm{T}$ is the corporate tax rate and $\mathrm{R}_{\mathrm{f}}$ is the risk rate.

Lenders expect payments of their loans both on the due date and at the contracted amount. They face the risk that payments are made too late and in for a lesser amount, including the risk of a total loss of capital and interest. To protect themselves against such contingencies lenders restrict their loans to certain amounts, require security and adjust their interest rates to compensate for the known risks; these adjustments are usually spreads over the risk-free rate of return reflecting the creditworthiness of the borrowers. The risk-free rate is that an asset would yield without any default, timing or exchange rate risk; as such, it is a non-observable theoretical construct. It is usually measured by the rates of return on government securities, which have the lowest risk, in any particular currency.

\section{Sources and Cost of Short Term Funds}

Sources of funds can be perceived in the light of their time duration, hence we have long-term, medium-term, and short-term sources of finance. It is conventional to look at short-term sources as those avenues with maturities of not more than one year. Thus, short-term capital constitutes funds obtained for one year or less (Ezirim, 2005). They are mostly employed for working capital requirements. Examples include overdraft advances from banks, credit purchases, deposits or advances from customers, bills receivable, and bills of exchange.

Medium or intermediate funds are such that are usually arranged for periods longer than one year but less than ten years. They include bank loans and overdrafts, hire purchase and installment credits arrangements, mortgage loans, equipment leasing, sale and lease back contracts. Long term sources involves those avenues for raising the long term/permanent capital attracts maturity dates of ten years more. Examples of long term or permanent capital include ordinary shares, preference share capital and debentures. Shares and debentures are hereby referred to as permanent capital because the funds supplied to the economic concerned units, in this case the firm, by investors when they buy the shares or debentures are not usually returnable (at least in the near future) to them except in the event of liquidation(Ezirim, 2005). However, redeemable preference shares and redeemable debentures are distinguished from permanent capital since they are usually returnable and are therefore described merely as long-term capital.

Capital generation can also be viewed from the angle of intra-ultra considerations. In other words, funds can be generated from internal sources and /or from external sources. Internally generated capital includes funds raised from within the firm itself. Internal sources are exemplified by provisions set aside out of profits, reserves and 
Cost of Capital and Corporate Earning of Nigeria Quoted Firms: A Multi-Dimensional Analysis of Quoted Firms in Nigeria

retained earnings (Ezirim, 2005). With respect to ultra considerations, funds are raised externally by way of permanent capital, long-term redeemable preferences shares and debentures, medium or intermediate capital, and short-term funds.

\section{Cost of Short-Term Capital}

The calculations of cost of short-term involves the manipulations in simple interest, simple discounts, compound interest and even annuities with relevant adjustments as demanded by each case in question.

$$
\mathrm{I}=\text { pit }
$$

Where $\mathrm{I}$ is the interest amount, $\mathrm{P}$ is the principal, $\mathrm{i}$ is the nominal rate of interest, and $\mathrm{t}$ is the time. To find the nominal rate of interest, we make $i$ the subject of the formula to have:

$$
i=\frac{I}{P_{t}}
$$

Thus, the interest rate per time period, I, equal to the interest amount in Naira divided by the product of principal and time which is actually the time here is the number of time periods (Ezirim, 2005). The above expression can be rearranged as follows:

$$
i=\frac{I}{P} \times \frac{1}{t} \text { Where } \mathrm{t}=\mathrm{n}
$$

Thus, the interest rate I, equal to the fractional interest cost per period I/P, times divided by the owner of time periods, $1 / n$.

To find the annual financing cost (AFC) for short-term financing sources, we use variation of the expression (15) above:

$$
\mathrm{AFC}=\frac{\text { Interest } \cos t s+\text { fees }}{\text { Usable funds }} \times \frac{365}{\text { maturity }(\text { days })}
$$

The above expression presupposes that short term funding source may involve fees in addition to the interest element. Equally, the term usable funds are used in place of principal or present value because some funds from some short term sources may not be available for the academic unit to use. The term, 365/maturity (days), converts the financing source to the annual rate (Ezirim, 2005). It is of note that the annual financing cost (AFC) is only an approximation of the true (effective) annual percentage rate (EAR), or (APR), of a loan. The AFC expressed above in (16) does not consider compounding and slightly understates the true APR. More so, the AFC as above is normally used for financing sources of 1 year or less. Putting these considerations into focus, the annual percentage rate (APR) or effective annual rate (EAR) for short-term financing is given by

$$
A P R=\left(1+\frac{\text { Interest } \cos t s+\text { fees }}{\text { Usable funds }}\right)^{m}-1
$$

When a business experiences difficulty in connection with liquid resources, it may be able to improve its situation by resorting to the use of trade credit facilities.

\section{Cost of Trade Credit}

Trade credit as a source of indirect financing has gained wider recognition, acceptability and sophisticated over time in the Nigerian investment hemisphere (Ezirim, 2005). If R limited buys raw materials worth $\$ 36$ million 
Cost of Capital and Corporate Earning of Nigeria Quoted Firms: A Multi-Dimensional Analysis of Quoted Firms in Nigeria

from its major suppliers each year, with a 5\% discount the net purchases are given by

$$
A P C=\frac{d}{1-d} \times \frac{N}{D C-D P}
$$

Where,

$$
\begin{aligned}
& \mathrm{APC}=\text { Approximate (annual) Percentage Cost } \\
& \mathrm{d}=\text { Discount rate } \\
& \mathrm{N}=\text { Number of days in a year } \\
& \mathrm{DC}=\text { Days of credit is outstanding } \\
& \mathrm{DP}=\text { Discount period }
\end{aligned}
$$

\section{Bank loans and Overdrafts}

These are short-term loans and overdrafts generally repayable within the period of one year. When extra cash is needed for working capital purposes, banks and overdrafts provide necessary sources of cash. Bank loans are compared with overdrafts here in the sense that in the case of former, interest will be paid for the full period of the loan, whereas in the case of the latter, interest is calculated on a day-to-day basis. In Nigeria, short-term bank loans and overdrafts constitute more than one half of the naira amounts of the total loans made by banks. In addition to commercial banks, merchant banks, finance house and even mortgage finance institutions finance short-term business needs. On a general note, short-term loans are employed to finance changes in working capital and temporary financing of fixed assets pending when agreements are reached for longer commitments. It is a norm for financial institutions to renew at maturity short-term loans and overdrafts especially when the customer financial condition and profitability is continually guaranteed (Ezirim, 2005). A number of types of short-term loans include bridge loans, take out commitments, receivables financing, unsecured business loans, and secured business loans.

\section{Cost of Bank Loans}

The cost of bank loans tends to have a linear relationship with the type of borrower, the riskiness of a given proposal and the prevailing state of the economy. Given a regime of interest rate deregulation rates are usually determined by the forces of demand and supply in the light of the factors identified above as determinants of interest rates (Ezirim, 2005). Thus, a high credit risk attracts high interest charges while a low or prime risk commands reasonably lower rates.

The effective annual rate of interest (costs of funds) is determined using the formula:

$$
E R_{s}=i=\frac{\operatorname{int} \operatorname{erest}(I)}{\operatorname{Pr} \operatorname{incipal}(P)}
$$

Where $\mathrm{ER}_{\mathrm{s}}$ is the effective rate of simple interest

Thus, suppose the loan is for 180 days, the effective rate can be determined using the expression:

$$
i=\left(1+\frac{r}{m}\right)^{m}-1
$$

Where $\mathrm{I}=$ effective rate, $\mathrm{r}=$ nominal rate and $\mathrm{m}=$ no. of conversion intervals

Discount Interest

A discount interest loan is exemplified by one in which the bank deducts the interest in advance or upfront. 


$$
\mathrm{ER}_{\mathrm{d}}=\frac{\text { Interest }(I)}{\text { Amount } \operatorname{Re} \text { cieved }(A R)}
$$

$$
d=\frac{\text { Interest }}{\text { Fcaevalue }- \text { int erest }}
$$

Alternatively we use the expression below

$$
\begin{aligned}
& E R_{d}=d=\frac{r \%}{1-r} \\
& E R_{D}=\left(1+\frac{\text { Interest } / m}{\text { facevalue }-(\text { int erest } / m}\right)^{2}-1
\end{aligned}
$$

If however we want to know how much the borrower would actually borrow if it requires a loan of we can use the formula:

$$
\text { Face } \operatorname{Value}(F)=\frac{F N}{1-r}
$$

Where $\mathrm{FN}=$ Funds needed and $\mathrm{r}=$ nominal rate in fraction. Thus,

$$
\begin{aligned}
& A E R_{a}=\frac{\text { int erest }}{(\text { Amountreceived }) / 2} \\
& P V=A=\sum R\left(\frac{1}{1+r}\right)^{t} \\
& E R_{a}=(1+r)^{m}-1
\end{aligned}
$$

\section{Commercial Papers}

A commercial paper is a short term debt instrument in the form of negotiable, bearer promissory notes issued for set maturities by reputable companies with the intent of borrowing short-term funds from interested public. Perhaps, the only collateral required for this type of facility is the good financial standing and repute of the firm attempting to raise funds; no specific security is required to back up the notes. Most commercial papers are issued for between 30 and 90 days, though issues of 180 and 270 days are obtainable. In Nigeria, commercial papers are not only issued by non-bank firms of repute, but also by bank themselves. In view of its unsecured nature, commercial papers are highly risky, though some are secured by the inventories of issuing companies. When commercial papers carry the guarantee of a bank to repay the sum due in event of a default, it is in all respects like a bankers' acceptance (Ezirim, 2005).

\section{Cost of Commercial Paper}

Commercial papers are sold at a discount from its par, or face, value. The interest received by the buyer or paid by the issuer of commercial paper is determined by the size of the discount and the length of time to maturity. The actual interest earned by the purchaser is obtained using similar procedure as we used in computing simple 
discounts.

$$
\operatorname{Pr}_{\mathrm{cp}} \%=\frac{F V-P}{P} \times \frac{100}{1}
$$

Where:

$$
\begin{aligned}
& \begin{array}{l}
\operatorname{Pr}_{\mathrm{c}} \%=\text { the periodic rate of interest paid on commercial paper } \\
\mathrm{FV} \quad=\text { the face value of the paper } \\
\mathrm{P} \quad=\text { the purchase price of papers. }
\end{array} \\
& \mathrm{AFC}=\frac{\text { int erest } \cos t s+\text { placement fee }}{\text { Usablefunds }} \times \frac{365}{\text { maturity (days) }}
\end{aligned}
$$

Where:

Usable funds $=$ Face amount - [interest costs $=$ placement fee]

Thus, denoting interest costs as I; placement fee as Pf, Face value or amount as fv; and Maturity (days) as MD; the above expression changes to:

$$
\begin{aligned}
& \mathrm{AFC}=\frac{I+P_{f}}{F v-\left(I+P_{f}\right)} \times \frac{365}{M D} \\
& E A R_{c p}=\left(1+\frac{K_{c p}}{m}\right)^{m}-1
\end{aligned}
$$

Where:

$\mathrm{EAR}_{\mathrm{cp}}=$ effective annual rate on commercial paper

$\mathrm{M}=$ the compounding frequency which we defined as conversion intervals.

$\mathrm{APR}_{\mathrm{cp}}=$ the normal annual rate

\section{Sources and Cost of Medium Term Funds}

Commercial banks and more especially merchant banks have been known to extend credit facilities in form of loans for periods more than one year. These facilities with maturities in excess of one year are known as term loans. This has constituted a worthwhile avenue for funding business and industrial concerns, the world over. Even in certain cases overdraft facilities can be renewed a number of times of the extent that when summed or put together their durations would be more than one year (Ezirim, 2005). A number of reasons have accounted for the development of term lending by banks and other financial institutions in Nigeria. First, the maturity patterns of term loans are easily amenable to the time frame attending to the borrowers needs. Thus, they can be manipulated to suit the borrowers' needs. Second, high-valued firms that can off-set the payment for fixed assets in a relatively short time may find it less advantageous to use equity or long term borrowing. In which case, medium-term loans become the preferred alternative. Third, benefits accruable to a company from the use of financial leverage can still be derived while using term borrowing without having to subject the firm to the problems associated with recalling bonds, debentures, or preferred stocks when no apparent need exists for the funds which were earlier generated using these means. Lastly, this type of loan is usually repaid according to earlier agreed upon schedule as reflected in the cash flow projections. This removes the difficulty of having to pay in a lump sum as may be required by a renewable short-term loan (Ezirim, 2005). 
Cost of Capital and Corporate Earning of Nigeria Quoted Firms: A Multi-Dimensional Analysis of Quoted Firms in Nigeria

Lucky Anyike Lucky

\section{Lines of Credit}

An economic agent that needs funds from time to time throughout the year for different or specific purposes may decide to approach a bank negotiates a line of credit. The line of credit represents an agreement that permits the economic unit to borrow funds up to an agreed limit at any time during the life of the agreement. The obvious benefits of a line of credit, compared with single loan, are that the economic unit does not have to renegotiate with the bank at every time funds are needed. Drawdown can be made at the shortest possible notice. It also enables the economic agent to plan for its future short-term financing requirements without having to know exactly how much it would have to borrow each month. Usually, a line of credit is agreed upon for a period of 1 year, with renewals being subject to re-negotiation each year. Banks usually takes into consideration such factors as the customers' personal characteristics-character, capacity, and capital-in determining the size of the credit line. The overall credit-worthiness of the unit is important in all credit considerations. For business customers, the need to produce a projected cash flow statement alongside the balance sheet and income statement cannot be overstressed (Ezirim, 2005).

\section{Cost Implications of Lines of Credit}

The interest rate chargeable on a line of credit is usually determined by adding to the prime-lending rate, a premium based on the borrower's credit-worthiness.

$$
\begin{aligned}
& \mathrm{I}=\text { Pit } \\
& \mathrm{I}=\mathrm{P} \text { x i x t }
\end{aligned}
$$

\section{Revolving Credit Agreement}

For a revolving credit agreement, usually called a revolver, the bank is committed to making loans to an economic unit up to the agreed credit limit whether or not the financial position of the economic unit is deteriorating or whether or not the bank lacks sufficient lonable funds to meet the loan requirements (Ezirim, 2005).

\section{Cost of Revolving Credit Agreements}

The annual financing cost of revolvers involves more rigorous manipulations than single-loan or line of credit arrangements.

$$
\begin{aligned}
& \mathrm{AFC}=\frac{\text { int erest } \cos t s+\text { commitment fee }}{\text { Usablefunds }} \times \frac{365}{\text { maturity }(\text { days })} \\
& \mathrm{AFC}=\frac{\text { int } \text { erest } \cos t s+\text { commitment fee }}{\text { Usablefunds }} \times \frac{365}{\text { maturity }(\text { days })}
\end{aligned}
$$

\section{Hire Purchase}

This is a useful method of indirect finance. By this method, an economic unit can obtain fixed assets by mere payment of the initial deposit, called an earnest sum or down payment, and thereafter pays agreed installments. The hire purchase arrangement is with interest and at times attracts service charges. There is no need to have one form of collateral or the other before entering into the agreement; as the assets, once in use, will normally generate enough profit to discharge agreed installments. Despite the somewhat glaring advantages of this indirect method of financing, hire purchase can attract a very high cost of financing, in the form of high rate of interest. Also, it calls for a very short period for which assets may be obtained and too many of such agreements can drain the profits of the company substantially (Ezirim, 2005). 
Cost of Capital and Corporate Earning of Nigeria Quoted Firms: A Multi-Dimensional Analysis of Quoted Firms in Nigeria

\section{Cost of Hire Purchase}

In hire purchase contracts, the buyer usually makes an initial deposit called down payment, or more traditionally, an earnest payment and further agrees to pay off the remainder in regular (or otherwise) installments. The initial down payment is a type of guarantee. Since the total payment is not completed on the day of purchase, a carrying cost (an extra charge for the privilege of deferred partial payments) is often included by the seller spreading alongside the installments. This carrying cost is a type of interest a price for using the installmental buying facility. Thus the total amount ( $\mathrm{Sn}$ ) paid by the buyer will represent the down payment (So) plus the series of the installmental payments which includes the carrying charges $\left(R_{1}+R_{2}+\ldots .+R_{n}\right)$.

$$
\mathrm{Sn}=\mathrm{So}+\left(\mathrm{R}_{1}+\mathrm{R}_{2}+\ldots .+\mathrm{R}_{\mathrm{n}}\right)
$$

Where $\mathrm{Sn}=$ total amount paid by purchaser

So $=$ down payment

$\mathrm{R}=$ partial payments plus interest made on installments.

\section{Direct Ratio Formula}

$$
r=\frac{6 m I}{3 B(n+1)+I(n-1)}
$$

\section{Factoring Accounts Receivables}

Account receivables' factoring concerns itself with the outright sale of the economic unit's receivables to a financial institution or consultant referred to as a factor. When this is done, and subsequent transfer made, the receivables no longer appears in the books (statement of affair) of the economic unit, say, a firm. The process of factoring takes off with a contract that clearly specifies the modalities for the agreement including terms of purchase and advance of funds, generated in the factoring exercise. The firm selling the receivables makes available the accounts to the factor for credit checking, appraisal an approval. Should the factor agree to take over the debts; the firm would notify its debtors of the sale of their accounts and instruct them to pay the factor directly. In this type of arrangement therefore, a firm may sell its book debts (at a discount, to allow a profit for the buyer). The reason for this may stem from the need to avoid tying down funds, needed for other operations, in the credit it allows to the customers (Ezirim, 2005).

\section{Cost of Factoring Receivables}

In factoring receivables, there is usually a service fee that is between $1 \%$ to $3 \%$ of the factored receivable. Annual Financing Cost before considering cost savings and bad-debt losses

$\mathrm{AFC}=\frac{\text { Interest } \cos t s+\text { fees }}{\text { Usable funds }} \times \frac{365}{\text { Days (maturity) }}$

$\mathrm{AFC}=\frac{\text { Interest Costs }- \text { Total } \cos t \text { savings }}{\text { Usablefunds }} \times \frac{365}{\text { Days to maturity }}$

\section{Lease Financing}

Equipment leasing involves entering into an agreement with a bank, a no-bank financial institution or even the 
Cost of Capital and Corporate Earning of Nigeria Quoted Firms: A Multi-Dimensional Analysis of Quoted Firms in Nigeria

manufacturer, for the use of a particular fixed asset at an agreed rental. A lease has been defined as a contract whereby, over the term of the lease, the lessor (owner) allows the lessee (user) the use of an asset in exchange for a promise by the latter to pay a series of lease payments called rentals. The workings of a typical lease arrangement are simple. First, the lessee selects the equipment and the dealer or the manufacturer from whom the equipment will be purchased. The lessee negotiates such aspect of the transaction as the price, specifications, warranties, and delivery date. He approaches the lessor, who in most cases is a bank or other financial institution, which buys the equipment from the dealer or manufacturer and leases it to the lessee for terms ranging from two to ten years or longer, depending on the nature of the equipment.

The appropriate discount factor would be the lessor's weighted cost of capital, which is equal to the applicable rate on debt instruments in the same risk class (Ezirim, 2005). Thus, the equilibrium lease-rental payment $\left(\mathrm{L}_{\mathrm{rp}}\right)$ is given by:

$$
\mathrm{NPV}_{\text {Lessor }}=\mathrm{C}_{\mathrm{o}}+\sum_{t=1}^{n} \frac{L_{t}(1-T)+T D e p_{t}}{(1+K)}
$$

Where:

$\mathrm{C}=$ cost of the asset

$\mathrm{n}=$ economic and tax depreciation life of asset

$\mathrm{k}=$ Lessor's cost of capital

From the Perspective of the Lessee

The lessee can make use of the leased asset through leasing or debt financing as earlier stated. This of course implies a simplistic assumption that the two options are perfect substitutes (Ezirim, 2005). Invariable for a given amount of extra tax shield offered by lease, there is a proportionate or equal amount reduced in the debt tax shield. The net present value of the lease is given by:

$\left.\mathrm{NPV}_{\mathrm{L}}=\mathrm{C}_{\mathrm{o}}-\mathrm{PV}\left[\mathrm{L}_{\mathrm{t}}(1-\mathrm{T})\right]-\mathrm{PV}\left(\mathrm{TDep}_{\mathrm{t}}\right)\right]$

The relevant discount rate is the after-tax cost of debt, since both lease payments and the foregone depreciation tax shields are risk-free and tax deductible (Ezirim, 2005). This guarantees the cost of debt to be equal to the cost implicit in the leasing arrangement.

$$
\mathrm{NPV}_{\text {lesser }}=0=\mathrm{C}+\sum_{t=1}^{n} \frac{L_{t}(1-T)}{(1+k)^{t}}+\sum_{t=1}^{n} \frac{T\left(\text { Dep }_{t}\right)}{(1+k)^{t}}
$$

Applying the annuity principle as in chapter 6, we have:

$\mathrm{NPV}_{\text {lessor }}=0-\mathrm{C}+\mathrm{L}_{\mathrm{t}}(1-\mathrm{T})(\mathrm{PVIFA} ; \mathrm{K}, \mathrm{n})+\mathrm{DTS}_{\mathrm{t}}(\mathrm{PVIFA}, \mathrm{k}, \mathrm{n})$

Cost of leasing $\quad=\quad-\sum_{t=1}^{9} \frac{L_{t}(1-T)}{\left[1+(1-T) K_{b}\right]}$

\section{Sources and Cost of Long Term Funds}

The permanent long-term funds available to the firm constitute the main components of its capital structure. Put together, they represent the firm's capital. On the part of individual households, they are veritable source of investments. The cost of capital for a firm is the charge for the use of funds from various sources. It represents the hurdle or cut off rate above which investment activities of financial agents must show a return in order to 
Cost of Capital and Corporate Earning of Nigeria Quoted Firms: A Multi-Dimensional Analysis of Quoted Firms in Nigeria

lend justification for their being carried out. What the efficient financial manager does is to ensure that this cost is reduced to the barest possible minimum so as to help maximize the owners' wealth. The cost of capital of a typical business firm can be classified into average cost of capital and marginal cost of capital.

Debentures and Bonds

Long term straight debt capital of business firms is basically defined in terms of debentures and bonds. A debenture has been described as a multiple loan of a company since it is contributed by large numbers of people and not by one person. The holders of debenture do not have claims on specific assets of the company (in most cases) but on the general credit-worthiness of the issuer. Being defined as above, a debenture becomes an unsecured bond, otherwise called a debenture bond. In contrast a secured bond or a mortgage bond is one, which possesses right of claims on specific assets of the issuer to real estate mentioned in the case of mortgage bonds (Ezirim, 2005).

\section{Cost of Debt}

Debt is used to represent a bond, debenture or loan stock. The cost of debt $\left(\mathrm{K}_{\mathrm{d}}\right)$ is the rate of interest specified at the time of the bond issue. The before tax cost of a bond issued at face value and redeemable after a designated future date, is the coupon or nominal rate of interest (Ezirim, 2005). Thus, if a debt is issued at par value

$$
K_{d}=\frac{I}{P}
$$

Where

$$
\begin{aligned}
& \mathrm{K}_{\mathrm{d}}= \text { Before tax cost of debt } \\
& \mathrm{I}= \text { Interest amount } \\
& \mathrm{P}= \text { Principal amount } \\
& p=\frac{I_{1}}{\left(1+K_{d}\right)}+\frac{I_{2}}{\left(1+K_{d}\right)^{2}}+\frac{I_{3}}{\left(1+K_{d}\right)^{3}}+\ldots \ldots+\frac{I_{20} P_{20}}{\left(1+K_{d}\right)^{20}}
\end{aligned}
$$

This is seen in view of the fact that from example 1,

$$
P_{o}=\sum_{t=1} \frac{X_{t}}{\left(1+K_{d}\right)}+\frac{P_{n}}{\left(1+K_{d}\right)^{n}}
$$

Where

$\mathrm{P}_{\mathrm{o}}=$ Principal or present value of debt

$\mathrm{X}=$ the regular interest payment or cash outflow to bond holders

$\mathrm{P}_{\mathrm{n}}=$ Terminal amount to be paid to the bond holders

$\mathrm{K}_{\mathrm{d}}=$ Cost of debt

$\mathrm{t} \quad=\quad$ time periods over the years till $n$ maturity date; here final $\mathrm{t}=\mathrm{n}$

\section{Cost of Debt Issued at a Premium or Discount}

In situations where the given debt instrument is issued at a premium or discount, the cost of debt will differ from the coupon rate of interest. Considerations are also given when the resulting premium or discount is amortized for tax purpose, over a given period (Ezirim, 2005). On the stead, the expression (44) below would be the best formula to apply in such an instance. Thus, 


$$
K_{d}=\frac{(1-t)\left[1+\frac{1}{n}(F-P)\right]}{\frac{1}{2}(F+P)}
$$

Where,

$\mathrm{F}=$ face value of debt

$\mathrm{P}=$ price at which the debt is sold

$\mathrm{N}=$ the number of years to maturity

$\mathrm{I}=$ fixed interest charge.

\section{Cost of Perpetual Debt}

When a company's debt is issued in perpetuity, its cost of debt, in that regard, can be calculated by dividing the fixed interest charges I by the price at which the debt is sold, after adjusting for the effect of tax. Thus, the cost of a perpetual debt is given by

After-tax cost of debt $\left(\mathrm{K}_{\mathrm{d}}\right)=\frac{1}{p}(1-t)$

Where, I, $\mathrm{p}$ and $\mathrm{t}$ are as defined earlier.

Notice that this perpetuality can arise in two ways:

(a) It may issue perpetual bonds from the onset, in which case this becomes part of the permanent capital (a case of issue of irredeemable bonds).

(b) It may maintain a policy of retaining a constant amount of bonds in its capital portfolio.

Thus, when once old bonds are redeemed, replacement would have been made aforetime by new bonds.

\section{Preference Shares Capital}

Preference shares are distinguished from ordinary shares at some inherent preferential right the former possess over the equity holders in terms of profits distribution during the life of a company; and over surplus asset in the event of winding up. In other words, they receive preferred dividend as well as priority claims over ordinary shareholders. The dividend paid to preference shareholders comes out of the profits after tax (PAT) of the company. This has been advanced as one of the reasons it attract higher cost than borrowed funds. Preferred stock, as it is sometimes called, possess some features of ordinary shares, especially in relation to the theoretical foundations that they are not suppose to be redeem or have maturities, having the element of perpetuity discussion in our introduction to mathematic of finance. Like ordinary shares dividends, preferred dividend comes from the PAT of the firm. Postponement or non payment of dividends on both shares would not necessarily amount to the company being liquidated on grounds of insolvency (Ezirim, 2005). On the other hand, they have some features of debentures or bonds especially when we consider that their dividends are limited as is the case with bondholders who receive fixed interest. Preferred dividend and interest on debentures are contractually determined, in most cases as a percentage of the par values of the instruments. To the extent to which preference shares have some characteristic of common shares and as well some features of debentures, we can refer to them as hybrid securities.

Cost of Irredeemable Preference Shares Capital

Preference shareholders receive a type of dividend called preference dividend. The cost of preference capital 
Cost of Capital and Corporate Earning of Nigeria Quoted Firms: A Multi-Dimensional Analysis of Quoted Firms in Nigeria

must, therefore, be related to the expected dividend of the holders of this kind of shares. Thus, the cost of preference shares in this instant will be given by,

$$
K_{p}=\frac{D_{p}}{P_{o}}
$$

Where

$\mathrm{K}_{\mathrm{p}}=$ Cost of preference capital

$\mathrm{D}_{\mathrm{p}}=$ Preference dividend, usually fixed

$\mathrm{P}_{\mathrm{o}}=$ Current page per preference share

$$
K_{p}=\frac{\left[D_{p}+\frac{1}{n}(F-P)\right]}{\frac{1}{2}(F+P)}
$$

\section{Cost of Eternal Equity Capital}

Using the dividend model, the underlying principle relevant to us here is that the price of the shares of a company is determined by the expected returns by its shareholders. These returns are composed of the expected stream of dividends (Ezirim, 2005). Given the growth in dividend expectation at a rate g, the value of the shares is given by:

$$
P_{o}=\frac{D_{1}}{\left(1+K_{e}\right)}+\frac{D_{2}}{\left(1+K_{e}\right)^{2}}+\ldots \ldots+\frac{D_{n}}{\left(1+K_{e}\right)^{n}}
$$

Where $P_{o}=$ Present value of the share, $K_{e}$ is the cost of equity capital, and $D_{1}, D_{2} \ldots . D_{n}$ is the stream of dividends from period 1 to $\mathrm{n}$. applying the growth rate $\mathrm{g}$ concept, expression (49) turns to:

$$
P_{o}=\frac{D_{0}(1+g)^{1}}{\left(1+K_{e}\right)}+\frac{D_{0}(1+g)^{2}}{\left(1+K_{e}\right)^{2}}+\ldots \ldots . .+\frac{D_{0}(1+g)^{n}}{\left(1+k_{e}\right)^{n}}
$$

Expression (17.10) can be generalized into:

$$
P_{o}=\sum_{t=0}^{n=\infty} \frac{D_{o}(1+g)^{t}}{\left(1+K_{e}\right)^{t}}
$$

Where $D_{0}=$ Dividend at time zero, and $g$ is the growth rate which in this case is considered perpetual.

A look at expression of the equations above reveals that the cost of equity, $K_{e}$, is the rate of return, which equates the two sides of the equation (Ezirim, 2005). Thus, it has been defined as the required rate of return, which equates the present value of the expected dividends with the market value of the share (Pandey, 1979). If we decompose expression (51) we get

$$
P_{o}=\frac{D_{0}(1+g)}{K_{e}-g}=\frac{D_{1}}{K_{e}-g}
$$

We can further solve for $\mathrm{K}_{\mathrm{e}}$ in (17.12) to have 
Cost of Capital and Corporate Earning of Nigeria Quoted Firms: A Multi-Dimensional Analysis of Quoted Firms in Nigeria

$$
K_{e}=\frac{D_{1}}{P_{o}}+g
$$

Cost of equity under zero growth rate in dividend

For a firm that operates dividend policy of $100 \%$ pay-out ratio, i.e. an all dividend firm there is no expectations as to growth in both earnings and dividends, such that $g=0$, under this situation the cost of equity will be given as

$$
K_{e}=\frac{D}{P_{o}} ; \quad \text { where } \mathrm{g}=0
$$

Upon closer observation on expression (54) we see that the R.H.S is the ratio of dividend to the price. Thus, the cost of equity under a $100 \%$ dividend payout ratio is equal to the dividend-price ratio.

Floatation Cost in Equity Issue

The cost of eternal equity or new issue of ordinary shares is normally adjusted for floatation costs. Like we stated earlier, floatation costs are associated with new issue of securities. Floatation costs have a way of restricting the company from realizing the full market value per share. Thus, the company must relinquish a part of the share price as floatation costs (Ezirim, 2005). Thus, if we denote this fraction of the share price as $f$, then the cost of new issue of equity share will be given by

$$
K_{e}=\frac{D_{1}}{P_{o}(1-f)}+g
$$

\section{Using the Earnings Model}

The cost of equity can be computed using the earnings model. In this model the cost of equity can be derived as the earnings per share to the current market price per share. Thus,

$$
K_{e}=\frac{E_{1}}{P_{o}}
$$

\section{Retained Earnings}

The cost of retained earnings is given by the same formula as in expression (56) since it is the expected return by the ordinary shareholders on their investment. Thus,

$$
K_{r}=\frac{D}{P_{o}}+g
$$

From the above, it seems that $\mathrm{K}_{\mathrm{e}}$ is equal to $\mathrm{K}_{\mathrm{r}}$. This can only be true if there is no withholding tax on dividend, personal tax, brokerage, costs, and floatation costs of new issues. Adjusting for all these, we can use expression (57) below to compute cost of retention. $\mathrm{K}_{\mathrm{r}}$ :

$$
\mathrm{K}_{\mathrm{r}}=\mathrm{K}_{\mathrm{e}}\left(1-\mathrm{t}_{\mathrm{p}}\right)(1-\mathrm{B})
$$

Where

$$
\begin{aligned}
& \mathrm{K}_{\mathrm{r}}=\text { required rate of return on retained earnings } \\
& \mathrm{K}_{\mathrm{e}}=\text { shareholders required rate of return }
\end{aligned}
$$


Cost of Capital and Corporate Earning of Nigeria Quoted Firms: A Multi-Dimensional Analysis of Quoted Firms in Nigeria

$\mathrm{t}_{\mathrm{p}}=$ personal tax rate of shareholders

$\mathrm{B}=$ percentage brokerage cost.

\section{Convertible Securities}

A convertible security is used to describe a bond, debenture or preference share, usually unsecured, that has the element of being converted into equally after an agreed time at a specified price or at the ruling market price at the time of such conversion. It can be termed equity deferred. The expected stream of receipts from a convertible security includes the relevant interest or preference dividend and the expected conversion price (Ezirim, 2005). The expected conversion price it has been argued, relates to the expected future market price per equity share at some future date, multiplied by the number of common shares into which the security should be the discount rate that equates the after-tax interest (or preference dividend) plus the expected conversion price with the issue price of the convertible security (Pandey, 2005) the cost can be found using expression below.

$$
V_{c}=\sum_{t=1}^{n} \frac{I(1-t)}{\left(1+K_{e}\right)^{t}}+\frac{C_{n}}{\left(1+K_{e}\right)^{n}}
$$

Where

$$
\begin{aligned}
& \mathrm{V}_{\mathrm{c}}=\text { Issue price of convertible bond at time } 0 . \\
& \mathrm{I}=\text { Annual interest payments } \\
& \mathrm{t}=\text { Corporate tax rate } \\
& \mathrm{n}=\text { Time horizon for conversion price at the end of the nth period } \\
& \mathrm{C}_{\mathrm{n}}=\text { Expected conversion price }
\end{aligned}
$$

If the security is preference capital, than our $I$ factor will change to $D_{p}$ and the tax factor $(1-t)$ will disappear to have.

$$
\mathrm{V}_{\mathrm{c}}=\sum_{t=1}^{n} \frac{D_{p}}{\left(1+K_{e}\right)^{t}}+\frac{C_{n}}{\left(1+K_{e}\right)^{n}}
$$

The cost of convertible security $\mathrm{K}_{\mathrm{c}}$ can be calculated from (17.19) and (17-20), as applicable, using the trial and error method.

\section{Empirical Review}

Anyamaobi and Lucky (2017) examined corporate characteristics and value creation of quoted manufacturing firms in Nigeria. The objective was to examine if factors within the control of management affects corporate value. Cross sectional data was sourced from financial statement of twenty quoted manufacturing firms. Market value was proxy for dependent variable while asset tangibility, return on investment, risk, liquidity, firm size, debt equity ratio, dividend payout ratio, retention ratio, corporate governance, management efficiency and cost of capital was proxy for independent variables. After cross examination of the validity of the pooled effect, fixed effect and the random effect, the study accepts the fixed effect model. Findings reveal that assets tangibility, return on investment, debt equity ratio, retention ratio, management efficiency and cost of capital have positive effect on the market value of the quoted manufacturing firms while risk, liquidity, firm size and corporate governance have negative effect on the market value.

Bitro and John, (2001) aimed at finding out the effect of growth opportunities on debts risks and cost which will lead to finding a new debt cost and that utilizing the growth opportunities well lead to overcoming investment problem partially. The study also indicated that high risk debts might discourage investment, because 
Cost of Capital and Corporate Earning of Nigeria Quoted Firms: A Multi-Dimensional Analysis of Quoted Firms in Nigeria

it was found that the relationship in some companies was negative.

Braunstein (2002) conducted a study addressing capital cost in communication and facilities sector at California, and studied the relationship between cost of capital invested in local rural areas communication and expected return. The study revealed that return on owner's equity increased during the study period from $11.8 \%$ to $13.4 \%$ and return on investment for the same period increased from $6.84 \%$ to $9.11 \%$.

Kareem (2006) conducted a study examining and assessing the relationship between capital cost using weighted average capital cost and market returns for shares as well as identifying type and nature of the relationship between financing cost and market returns for shares in addition to and share market return, on a sample of (37) industrial companies for the period 1994 - 2004. The study revealed a significant relationship between weighted average capital cost and stocks market returns, where external (debt) financing has more affection stocks market return compared to internal (owned) financing.

Abdel (2008) attempted to find out the effect of financing decision on institutions' financial performance and tax and financing cost effects. The study showed that positive financial performance is contingent on the institution ability in forming the optimal mix of financial structure, the extent to which available financing resources are used in a pace equal to its economic assets turnover to assure forming a wealth, and increasing growth rate, which finally results in maximizing the corporation value meanwhile financial structure is considered as basic element in assessing and measuring corporate financial performance as it is difficult to talk about an economic corporation without financial structure.

P-Eriotis, Frangouli and Ventoura (2011) found that firms financed with equity are more profitable as compare to those financed by debt. If debt amount is high than a part of its profits is given as interest which ultimately reduces its profits. Capital structure choice has vital importance. Debt to equity ratio is used in order to examine its impact on firm's profitability. Fixed effect model and random effect model are used. It is analyzed that debt negatively impacts a firm's profitability because mostly the cost of debt is high than profits of the firm. They also concluded that firms liked to compete with one and another rather than cooperating.

\section{Research Methodology}

Descriptive and longitudinal design was employed with a view to making statistical inferences on factors that determine corporate earnings of the quoted firms. A Sampling frame of 20 quoted firms was selected using random sampling techniques. The required cross-sectional data were sourced from annual reports of the firms and stock exchange factbook from 2011-2016.

\section{Analytical Framework and Empirical Model Specification}

This analysis is carried out within a panel data estimation framework. The preference of this estimation method is not only because it enables a cross-sectional time series analysis which usually makes provision for broader set of data points, but also because of its ability to control for heterogeneity and endogencity issues. Hence panel data estimation allows for the control of individual-specific effects usually unobservable which may be correlated with other explanatory variables included in the specification of the relationship between dependent and explanatory variables (Hausman and Taylor, 1981). The basic framework for panel data regression takes the form:

$$
Y_{i t}=\beta X^{{ }_{i t}}+\alpha Z{ }_{i}+\varepsilon_{i t}
$$

In the equation above, the heterogeneity or individual effect is $Z^{i}$ which may represent a constant term and a 
Cost of Capital and Corporate Earning of Nigeria Quoted Firms: A Multi-Dimensional Analysis of Quoted Firms in Nigeria

set of observable and unobservable variables. When the individual effect $Z^{\prime}{ }_{i}$ contains only a constant term, OLS estimation provides a consistent and efficient estimates of the underlying parameters (Kyereboah-Coleman, 2007); hut if $Z^{\prime}{ }_{i}$ is un-observable and correlated

with $X_{i t}$, then emerges the need to use other estimation method because OLS will give rise to biased and inconsistent estimates.

Similarly for endogeneity issues, it is generally assumed that the explanatory variables located on the right hand side of the regression equation are statistically independent of the disturbance $\varepsilon_{i t}$ such that the disturbance term $\varepsilon_{i t}$ is assumed to be uncorrelated with columns of' the parameters $X_{i t}$ and $Z_{i t}$ as stated in equation (1), and has zero mean and constant variance $\sigma^{2} \eta$ (Hausman and Taylor, 1981). If this assumption is violated, then OLS estimation will yield biased estimates of the underlying parameters of $\beta$ (Mayston, 2002).Hence, endogeneitv problems arise when the explanatory variables are correlated with the disturbance term $\varepsilon_{i t}$ (Mayston, 2002; Hausman and Taylor, 1981). In order to circumvent these problems, panel estimation techniques of fixed and random effects will be adopted in this study, in addition to the traditional pooled regression estimation. Decisions will be made between the fixed and random effect models using the Hausman specification test. The panel model for the study is specified base on the modified model of Lawal, Edwin, Kiyanjui and Kayode (2014).

$$
Y_{i t}=\beta X^{\prime}{ }_{i t}+\alpha Z_{i}^{\prime}+\varepsilon_{i t}
$$

Where:

$\mathrm{Y}=$ dependent variable

$\mathrm{D}=$ independent variable

$\beta_{o}=$ intercept

$\beta_{i}=$ coefficient of the explanatory variable

$\mathrm{e} \quad=$ error term

$\mathrm{I}=$ cross-sectional variable

$\mathrm{T}=$ time series variable

\section{Model I: Short Term Cost of Capital}

Pooled regression specification

$E P S_{i}=\alpha o+\alpha_{1} C T C_{1_{i}}+\alpha_{2} C B L_{2 i}+\alpha_{3} C C P_{3 i t}+\alpha_{4} C B A_{4 i t}+\varepsilon 1_{i t}$

(63) 
Cost of Capital and Corporate Earning of Nigeria Quoted Firms: A Multi-Dimensional Analysis of Quoted Firms in Nigeria

\section{Fixed Effect Model Specification}

$E P S_{i}=\alpha o+\alpha_{1} C T C_{1 i}+\alpha_{2} C B L_{2 i}+\alpha_{3} C C P_{3 i t}+\alpha_{4} C B A_{4 i t}+\varepsilon_{1 i t}+\alpha_{5} R R \sum_{i}^{9}=1 \alpha_{i} i d u m+\varepsilon 1_{i t}(64)$

\section{Random effect model specification}

$E P S_{i}=\alpha o+\alpha_{1} C T C_{1 i}+\alpha_{2} C B L_{2 i}+\alpha_{3} C C P_{3 i t}+\alpha_{4} C B A_{4 i t}+\varepsilon 1_{i t}+\mu i+\varepsilon 1_{i t}$

Where

EPS $=$ Earnings Per Share

$\mathrm{CTC}=$ Cost of Trade Credit

$\mathrm{CBL}=$ Cost of Short Term Bank Loans

$\mathrm{CCP}=$ Cost of Commercial Paper

$\mathrm{CBA}=$ Cost of Bankers Acceptance

$\varepsilon 1=$ Stochastic or disturbance/error term.

$\mathrm{t}=$ Time dimension of the variables

$\alpha 0=$ Constant or intercept.

Model II: Medium Term Cost of Capital

Pooled regression specification

$E P S_{i}=\alpha O+\alpha_{1} C L C_{1 i}+\alpha_{2} C R C_{2 i}+\alpha_{3} C H P_{3 i t}+\alpha_{4} C O L_{4 i t}+\varepsilon 1_{i t}$

(66)

Fixed Effect Model Specification

$E P S_{i}=\alpha o+\alpha_{1} C L C_{1 i}+\alpha_{2} C R C_{2 i}+\alpha_{3} C H P_{3 i t}+\alpha_{4} C O L_{4 i t}+\varepsilon 1_{i t} \quad \sum_{i}^{9}=1 \alpha_{i} i d u m+\varepsilon 1_{i t}$ (67)

Random effect model specification

$E P S_{i}=\alpha o+\alpha_{1} C L C_{1 i}+\alpha_{2} C R C_{2 i}+\alpha_{3} C H P_{3 i t}+\alpha_{4} C O L_{4 i t}+\varepsilon 1_{i t}+\mu i+\varepsilon 1_{i t}$

Where

EPS $=$ Earnings Per Share

$\mathrm{CLC}=$ Cost of Line of Credit

$\mathrm{CRC}=$ Cost of Revolving Credit

$\mathrm{CHP}=$ Cost of Hire Purchase

$\mathrm{COL}=$ Cost of Operating Lease

$\varepsilon 1=$ Stochastic or disturbance/error term.

$\mathrm{t}=$ Time dimension of the variables

$\alpha 0=$ Constant or intercept.

Model III: Cost of Long Term Capital

Pooled regression specification

$E P S_{i}=\alpha o+\alpha_{1} C D_{1_{i}}+\alpha_{2} C P S_{2 i}+\alpha_{3} C E_{3 i t}+\varepsilon 1_{i t}$

Fixed Effect Model Specification

$E P S_{i}=\alpha o+\alpha_{1} C D_{1_{i}}+\alpha_{2} C P S_{2 i}+\alpha_{3} C E_{3 i t}+\varepsilon 1_{i t} \quad \sum_{i}^{9}=1 \alpha_{i} i d u m+\varepsilon 1_{i t}$

Random effect model specification

$E P S_{i}=\alpha o+\alpha_{1} C D_{1 i}+\alpha_{2} C P S_{2 i}+\alpha_{3} C E_{3 i t}+\varepsilon 1_{i t}+\mu i+\varepsilon 1_{i t}$

Where

EPS $=$ Earnings Per Share 
Cost of Capital and Corporate Earning of Nigeria Quoted Firms: A Multi-Dimensional Analysis of Quoted Firms in Nigeria

$\mathrm{CD}=$ Cost of Debt

$\mathrm{CPS}=$ Cost of Preference Share Capital

$\mathrm{CE}=$ Cost of Equity

$\varepsilon 1=$ Stochastic or disturbance/error term.

$\mathrm{t}=$ Time dimension of the variables

$\alpha 0=$ Constant or intercept.

\section{Presentation and Analysis of Results}

Table 1: Short Term Cost of Fund and Corporate Earnings

The effect of short term cost of capital and corporate earnings of the quoted firms is presented in the table below:

\begin{tabular}{|c|c|c|c|c|c|c|c|c|c|}
\hline Variable & Pooled Effect & & & effect & & & Random effect & & \\
\hline & $\beta$ coefficient & T. stat & p. value & $\beta$ coefficient & T. stat & p. value & $\beta$ coefficient & T. stat & p. value \\
\hline CTC & 0.148625 & 1.507153 & 0.1376 & 0.078310 & 0.604458 & 0.5486 & 0.113456 & 1.016388 & 0.3140 \\
\hline $\mathrm{CCP}$ & -0.192515 & -1.607329 & 0.1138 & 0.052741 & 0.341880 & 0.7340 & -0.062976 & -0.470742 & 0.6397 \\
\hline CBL & 0.622104 & 5.390628 & 0.0000 & 0.594419 & 4.236145 & 0.0001 & 0.621364 & 4.983027 & 0.0000 \\
\hline CBA & 1.795160 & 1.289044 & 0.2029 & 1.930450 & 1.463949 & 0.1502 & 1.903991 & 1.471854 & 0.1469 \\
\hline $\mathrm{C}$ & 4.587419 & 2.231603 & 0.0298 & 2.965692 & 1.204819 & 0.2346 & 3.532629 & 1.590599 & 0.1175 \\
\hline $\mathrm{R}^{2}$ & 0.439038 & & & 0.631479 & & & 0.360257 & & \\
\hline $\operatorname{Adj}^{2}$ & 0.397486 & & & 0.525017 & & & 0.312868 & & \\
\hline F-stat & 10.56582 & & & 5.931506 & & & 7.602212 & & \\
\hline F- Prob & 0.000002 & & & 0.000003 & & & 0.000062 & & \\
\hline D W & 1.094674 & & & 2.139366 & & & 1.773717 & & \\
\hline \multicolumn{2}{|c|}{ Effects Test } & & Statistic & d.f. & Prob. & & & & \\
\hline \multicolumn{2}{|c|}{ Cross-section F } & & 2.610975 & $(9,45)$ & 0.0162 & & & & \\
\hline \multicolumn{2}{|c|}{ Cross-section Chi-square } & & 24.789052 & 9 & 0.0032 & & & & \\
\hline \multicolumn{10}{|c|}{ Hausman Test } \\
\hline \multicolumn{2}{|c|}{ Cross-section random } & & 2.547784 & 4 & 0.0001 & & & & \\
\hline
\end{tabular}

Source: Computed by Researcher from E-view 9.0

The Hausman test is used in panel data to ascertain the most appropriate model. This test was conducted on the effect of short term cost of capital and corporate earnings of quoted firms in Nigeria as reported in the table 1 above. The p-value obtained from Hauseman test was significant; therefore the fixed effects model was the most appropriate model.

From the table the R-square and the adjusted R-square proved that $43.9 \%$ and 39.7 variation on corporate earnings can be explained by the variation on the cost of various component of short term cost of capital. The F-statistic value of 10.56582 and the probability of $0.000002(\mathrm{P}<0.05)$ shows that the independent variables are jointly statistically significant in explaining changes in the dependent variable. Specifically, the results from the table show that all the independent variables have positive impact on corporate earnings. The $\beta$ coefficient of $0.07 \mathrm{CTC}, 0.05 \mathrm{CCP}, 0.59 \mathrm{CBL}$ and $1.93 \mathrm{CBA}$ proved that a unit increase on the variables will lead to $0.7 \%, 0.5 \%$, 
Cost of Capital and Corporate Earning of Nigeria Quoted Firms: A Multi-Dimensional Analysis of Quoted Firms in Nigeria

$5.9 \%$ and $19.3 \%$ increase on the dependent variables. The T-statistics and the probability value shows that only commercial banks short term cost of capital is statistically significant while others are statistically not significant at $5 \%$ level of significance. The insignificant impact of the variables could be traced to the fact that the companies do not utilize some of the credit facilities in Nigeria. The positive effect of the variables are contrary to the expectation of the results and could be traced to the fact that the management formulate policies that will hedge against the negative impact of cost of capital on corporate earnings. This findings confirms the findings of Osiegbu (2005) on the positive effect of interest rate and commercial bank credit which he blamed unstructured nature of the financial market that does not give borrowers alternative source of funding.

Table 2: Medium Term Cost of Fund and Corporate Earnings

The effect of medium term cost of capital and corporate earnings of the quoted firms is presented in the table below

\begin{tabular}{|c|c|c|c|c|c|c|c|c|c|}
\hline Variable & Pooled Effect & & & effect & & & Random effect & & \\
\hline & $\begin{array}{l}\beta \\
\text { coefficient }\end{array}$ & T. stat & p. value & $\beta$ coefficient & T. stat & p. value & $\beta$ coefficient & T. stat & p. value \\
\hline $\mathrm{CRC}$ & 0.031876 & 0.455749 & 0.6504 & -0.089468 & -1.326536 & 0.1914 & -0.059849 & -0.928629 & 0.3572 \\
\hline CLC & -0.005308 & -0.133859 & 0.8940 & -0.026842 & -0.842099 & 0.4042 & -0.021463 & -0.679823 & 0.4995 \\
\hline $\mathrm{CL}$ & 0.091047 & 0.603850 & 0.5485 & 0.233101 & 1.787617 & 0.0806 & 0.201724 & 1.579846 & 0.1200 \\
\hline CHP & 0.006578 & 0.177444 & 0.8598 & -0.011139 & -0.334829 & 0.7393 & -0.005666 & -0.175118 & 0.8616 \\
\hline $\mathrm{C}$ & 11.74427 & 18.79303 & 0.0000 & 12.17721 & 22.19156 & 0.0000 & 12.05265 & 19.07939 & 0.0000 \\
\hline $\mathrm{R}^{2}$ & 0.010604 & & & 0.515421 & & & 0.071086 & & \\
\hline $\operatorname{Adj}^{2}$ & -0.062685 & & & 0.375432 & & & 0.002277 & & \\
\hline F-stat & 0.144687 & & & 3.681857 & & & 1.033094 & & \\
\hline F- Prob & 0.964582 & & & 0.000543 & & & 0.398680 & & \\
\hline $\mathrm{DW}$ & 1.257586 & & & 2.296105 & & & 1.992811 & & \\
\hline $\begin{array}{l}\text { Redundan } \\
\text { Tests } \\
\text { Effects Test }\end{array}$ & Fixed Effects & Statistic & d.f. & Prob. & & & & & \\
\hline & Cross-section F & 5.208824 & $(9,45)$ & 0.0001 & & & & & \\
\hline Cross-sec & tion Chi-square & 42.115058 & 9 & 0.0000 & & & & & \\
\hline \multicolumn{10}{|c|}{ Correlated Random Effects - Hausman Test } \\
\hline Cross-s & ection random & 2.714876 & 4 & 0.6066 & & & & & \\
\hline
\end{tabular}

Source: Computed by Researcher from E-view 9.0

The Hausman test is used in panel data to ascertain the most appropriate model. This test was conducted on the effect of medium term cost of capital and corporate earnings of quoted firms in Nigeria as reported in the table 2 above. The p-value obtained from Hauseman test was not significant; therefore the random effects model was the most appropriate model.

From the table the R-square and the adjusted R-square proved that $7.1 \%$ and $0.2 \%$ variation on corporate 
Cost of Capital and Corporate Earning of Nigeria Quoted Firms: A Multi-Dimensional Analysis of Quoted Firms in Nigeria

earnings can be explained by the variation on the cost of various component of medium term cost of capital. The F-statistic value of 1.0398680 and the probability of $0.398680(\mathrm{P}>0.05)$ shows that the independent variables are jointly statistically not significant in explaining changes in the dependent variable. Specifically, the results from the table show that all the independent variables have positive impact on corporate earnings. The $\beta$ coefficient of -0.59CRC, -0.02CLC, 0.201CL and -0.006CHP proved that a unit increase on the variables will lead to 5.9\%, $0.2 \%, 0.6 \%$ decrease on the dependent variables while the positive coefficient of $0.201 \mathrm{CL}$ will lead to $2.0 \%$ increase on corporate earnings. The T-statistics and the probability value shows that all the medium term cost of capital is statistically not at $5 \%$ level of significance. The negative effect of the variables, the littlie explained variation and insignificant impact of the variables could be traced to the fact that the companies do not utilize some of the credit facilities in Nigeria. The positive effect of the variable is contrary to the expectation of the results and could be traced to the fact that the management formulate policies that will hedge against the negative impact of cost of capital on corporate earnings while the negative effect confirm the a-priori expectation of the results, this findings confirm the findings of Bitro and John, (2001) that high risk debts might discourage investment, because it was found that the relationship in some companies was negative.

Table 3: Long Term Cost of Fund and Corporate Earnings

\begin{tabular}{|c|c|c|c|c|c|c|c|c|c|}
\hline \multirow[t]{2}{*}{ Variable } & \multicolumn{3}{|l|}{ Pooled Effect } & \multicolumn{3}{|l|}{ Fixed effect } & \multicolumn{3}{|l|}{ Random effect } \\
\hline & $\beta$ coefficient & T. stat & p. value & $\beta$ coefficient & T. stat & p. value & $\beta$ coefficient & T. stat & p. value \\
\hline $\mathrm{CD}$ & -0.001159 & -1.201734 & 0.2346 & -0.000534 & -0.615593 & 0.5412 & 11.24348 & 13.53105 & 0.0000 \\
\hline CPS & 0.447321 & 2.412354 & 0.0192 & 0.291708 & 1.664693 & 0.1028 & -0.000534 & -0.615593 & 0.5412 \\
\hline $\mathrm{CE}$ & -0.126445 & -0.964121 & 0.3392 & -0.060452 & -0.459210 & 0.6482 & 0.291708 & 1.664693 & 0.1028 \\
\hline $\mathrm{C}$ & 10.86029 & 13.32330 & 0.0000 & 11.24348 & 13.53105 & 0.0000 & -0.060452 & -0.459210 & 0.6482 \\
\hline $\mathrm{R}^{2}$ & 0.819022 & & & 0.489460 & & & 0.489460 & & \\
\hline $\operatorname{Adj}^{2}$ & 0.770969 & & & 0.356275 & & & 0.356275 & & \\
\hline F-statistic & 12.47687 & & & 3.675052 & & & 3.675052 & & \\
\hline F- Prob & 0.000000 & & & 0.000669 & & & 0.000669 & & \\
\hline D W & 1.519769 & & & 2.266686 & & & 2.266686 & & \\
\hline Effects $\mathrm{Te}$ & & & Statistic & d.f. & Prob. & & & & \\
\hline Cross-sec & on $\mathrm{F}$ & & 3.708518 & $(9,46)$ & 0.0015 & & & & \\
\hline Cross-sec & on Chi-square & & 32.188216 & 9 & 0.0002 & & & & \\
\hline \multicolumn{10}{|c|}{ Correlated Random Effects - Hausman Test } \\
\hline Cross-sec & on random & & 8.024643 & 3 & 0.0055 & & & & \\
\hline
\end{tabular}

Source: Computed by Researcher from E-view 9.0

The Hausman test is used in panel data to ascertain the most appropriate model. This test was conducted on the effect of long term cost of capital and corporate earnings of quoted firms in Nigeria as reported in the table 3 above. The p-value obtained from Hauseman test was significant; therefore the fixed effects model was the most appropriate model.

From the table the R-square and the adjusted R-square proved that $81.9 \%$ and $77 \%$ variation on corporate earnings can be explained by the variation on the cost of various component of short term cost of capital. The 
Cost of Capital and Corporate Earning of Nigeria Quoted Firms: A Multi-Dimensional Analysis of Quoted Firms in Nigeria

F-statistic value of 12.47687 and the probability of $0.000000(\mathrm{P}<0.05)$ shows that the independent variables are jointly statistically significant in explaining changes in the dependent variable. Specifically, the results from the table show that cost of debt and cost of equity have negative effect on corporate earnings while cost of preference share capital have positive effect on the dependent variable. The $\beta$ coefficient of $-0.00 \mathrm{CD}, 0.29 \mathrm{CPS}$, -0.060 proved that a unit increase on the variables will lead to $0.0 \%$ and $0.6 \%$, decrease on the dependent variables while the positive coefficient of $0.29 \mathrm{CPS}$ will lead to $2.9 \%$ increase on the corporate earnings of the quoted firms. The T-statistics and the probability value show cost of debt is statistically significant while cost of preference share capital and equity is statistically not significant at $5 \%$ level of significance. While the positive effect of the variable is contrary to the expectation of the results, the negative effect confirms the a-priori expectation of the results and validates the findings of Anyamaobi and Lucky (2017) on the positive effect of cost of capital on the value creation of quoted manufacturing firms in Nigeria.

\section{Conclusion and Recommendation}

This study investigated the relationship between cost of capital and corporate earnings of 20 firms listed on the floor of Nigerian stock exchange using time series data from 2011 - 2016. Cost of capital was disaggregated by short, medium and long term while corporate earning was proxy by earnings per share. From the findings of the study, we draw the following conclusion:

- That the relationship between costs of short term capital is statistically significant with corporate earnings, the model summary shows that the independent variables could only attest $63.1 \%$ and $52.5 \%$ variation while the F-statistics shows that the model is statistically significant.

- That the relationship between costs of medium term capital is statistically not significant with corporate earnings, the model summary shows that the independent variables could only attest $7.1 \%$ and $0.2 \%$ variation while the F-statistics shows that the model is statistically not significant.

- That the relationship between costs of long term capital is statistically significant with corporate earnings, the model summary shows that the independent variables could only attest $81.9 \%$ and $77.0 \%$ variation while the F-statistics shows that the model is statistically significant.

\section{Recommendation}

- Management should formulate internal policy that will enhance the realization of optimal capital structure of the firm which determines the combination of equity capital and debt capital as the capital structure of the firm and the business environment should be well diagnosed and tactical measures used to ensure that cost of capital does not affect the investment decision of the firms and the profitability.

- The environmental factors should be acknowledged in formulating cost of capital to avoid risk associated with inadequate or wrong capital structure of the firm to enhance profitability and external source of capital such as debt should be properly appraised and integrated with the investment policy of the firms to leverage the high cost of debt and its effect on investment and profitability.

- Cost of equity should be integrated with the objective of maximizing shareholders' wealth through investment policies and the regulatory authorities should formulate policies of minimizing the cost of capital on the investment decision of the listed firms.

\section{References}

Abdel, D., (2008).Financing decision under the influence of taxes and financing cost. Al-Baheth journal, 6; 17-31.

Anyamaobi, C., \& Lucky, A. L., (2017). Corporate Characteristics and Value Creation: A Panel Data Evidence 
Cost of Capital and Corporate Earning of Nigeria Quoted Firms: A Multi-Dimensional Analysis of Quoted Firms in Nigeria

of Nigeria Quoted Manufacturing Firms. World Journal of Finance and Investment Research, 2(1), 31-49.

Braunstein, Y., (2002). Cost of Capital Study for Telecommunications Utilities, Working paper, School of Information Management and Systems, University of California at Berkeley, Pp3.

Claus, J. \& Thomas, J. (2001). Equity risk premium as low as three percent? Evidence from analysts' earnings forecasts for domestic and international stocks. Journal of Finance, 56 (5), 1629-1666.

Easton, P. D. 2003. PE ratios, PEG ratios, and estimating the implied expected rate of return on equity capital. The Accounting Review 79 (1):73-95

Ezirim, B.C., (2005). Finance Dynamics Principles, Techniques \& Applications. Markowitz Centre for Research \& Development Port Harcourt.

Gode, D., \& Mohanram, P. (2003). Inferring the cost of capital using the Ohlson-Juettner model. Review of Accounting Studies, 8(4), 399-431.

Hausman, J. A., \& Taylor, W. E., (1981). Panel Data and Unobservable Individual Effect, Econometrical, 49(6), 1377-1398.

Kareem, A., (2006). Testing and assessing the relationship between capital cost and stock market returns, an empirical study on industrial companies listed at Amman stock exchange for the period $1994-2004$. Humanities Journal, 4(29), 1-24.

Kyereboah-Coleman, A., (2007). The impact of capital structure on the performance of microfinance institutions. Journal of Risk Finance, 8 (7),56-71.

Lawal, B. A, Edwin, T. K., Kiyanjui, M. W., and Adisa, M. K., (2014).Effects of Capital Structure on Firm's Performance: Empirical Study of Manufacturing Companies in Nigeria. Journal of Finance and Investment Analysis, 3,(4), 39-57.

Lee, C., D. Ng, and B. Swaminathan, 2004. International asset pricing: Evidence from cross section of implied cost of capital. Cornell University Working paper

Mayston, D. J., (2002). Tackling The Endogeneity Problem When Estimating the Relationship between School Spending and Pupils' Outcome, DFEE Research Report 328, Department Of Education and Skills, London.

Modiglinni , franco \& Miller Merton.H.,(1958).The Cost of Capital, Corporation Finance and the Theory of Investment. American Economic Review, 48, 261-297.

Ohlson, J., and B. Juettner-Nauroth, 2004, Expected EPS and EPS Growth as Determinants of Value, Working Paper, New York University.

P-Eroitis, Frangouli, \& Ventoura (2011). Profit Margin and Capital Structure. The Journal of Applied Research.

\section{Copyrights}

Copyright for this article is retained by the author(s), with first publication rights granted to the journal. 